\title{
Measuring methods for soil microbial activity and biomass ${ }^{1}$
}

\author{
HELVI HEINONEN-TANSKI, AILA METTÄLÄ and RIITTA SILVO \\ Department of Microbiology, University of Helsinki, \\ SF-00710 Helsinki, Finland
}

\begin{abstract}
The determining for the numbers of different soil microbial groups has some technical difficulties because of biological reasons. Therefore the measuring of cell components or metabolic activity of soil micro-organisms is often preferred.

The different measuring methods for determining the numbers of micro-organisms or microbial cell components or microbial enzymatic activities will be shortly reviewed.
\end{abstract}

\section{Introduction}

Living soil micro-organisms e.g. bacteria, microscopic fungi, protozoa and viruses are understood to form the microbial biomass of soil. Living organisms are usually considered to those which potentially can still metabolize or produce daughter cells. In practice it is very difficult to say which of the micro-organisms can still grow and metabolize because most of the cells in soil are not in active stage.

The methods for measuring soil microbial activity fall into three different categories: methods for determining the number of micro-organisms, methods for determining the content of cell compounds and methods for determining metabolic activity of soil micro-organisms.

We have studied the fitness of different methods for soil microbiology in order to find the most suitable methods for microbiological studies dealing with the effects of fertilization, cultivation or the use of pesticides.

\section{Determination of microbial numbers}

The classical method for measuring the number of soil micro-organisms is the determining of the "total number" of micro-organisms by plate counting or by MPN. Unfortunately, using these methods the soil micro-organism numbers obtained, are too low because the growth requirements for different micro-organisms are very different, as well as their $\mathrm{pH}$, redox-potential and temperature requirements. However, we use MPN and plate count method for determining the

\footnotetext{
' Presented in an Estonian-Finnish minisymposium for microbiology, 26th October, 1983 in Tallinn.
}

Index words: ATP-content, carbon dioxide formation, dehydrogenase activity, epifluorescent microscopy, ${ }^{3} \mathrm{H}$-thymidine incorporation, microautoradiography, nitrification potential 
"total number" of micro-organisms. We use a very poor soil extract medium of TAYLOR (1951). The incubation temperature is $15^{\circ} \mathrm{C}$ for four weeks.

We also have determined by cultivation methods the numbers for actinomycete, bacilli, cellulolytic and ureolytic micro-organisms (HeInONEN-TANSKI et al., 1984 and SiLvo, 1983).

The number of micro-organisms can also be determined by microscopic or electron microscopic methods. Stained cells, dead or living, can all be seen by light microscopy, so this method usually gives too high numbers. This problem can be avoided by using vital stains and fluorescence microscopy. A sophisticated method is the combination of fluorescence microscopy and autoradiography. This method is usual in water microbiology, but it should be useful in soil microbiology, too. Because this is a new method it will be described in more detail. The original method was developed by MEYER-REIL (1978) and Fuhrman and Azam (1982) and modified by RIEMANN (1982).

i) ${ }^{3} \mathrm{H}$-labelled thymidine or glucose is added to a diluted soil sample, incubated and fixed with formalin.

ii) The sample is stained with a vital stain such as acridine orange.

iii) The sample is filtered through a filter,

iv) An extra-pure glass slide is dipped into gelatine. After drying, the gelatine is wiped off the back side and the filter along with the sample is fixed on the gelatine coated side.

v) The radioactivities are detected by microautoradiography.

The cells which are metabolically active specifically incorporate radioactivity into their cells, and only these cells can be seen during an ordinary light microscopic examination. All the living cells could be seen in an epifluorescence illumination. If the same filter is examined by both these illuminations, it is possible to count which cells are living and metabolically active.
We have incubated a soil sample dilution (1 : $\left.10^{3}\right) 2.5 \mathrm{~h}$ with ${ }^{3} \mathrm{H}$-thymidine. We filtered the thymidine-treated and stained sample (1: 100) through a $0.2 \mu \mathrm{m}$ polycarbonate filter with d $25 \mathrm{~mm}$. The filter was examined after the autoradiography with an epifluorescence microscope. This method seemed to be very promising.

\section{Determination of cell components}

Microbial activity of soil micro-organisms has been assayed by measuring the DNA of the soil. This method has been presented in detail by TORSVIK and GoKsøyr (1978).

ATP content (adenosine triphosphate content) of soil micro-organisms is measured luminometrically in our department with the luciferin-luciferase system (ANON. 1979). The ATP of the soil sample is first diluted to tris-EDTA buffer (pH 7.75). The ATP is then extracted with a commercial extraction solution in a measuring cuvette which is set in the measuring head of the luminometer. The luciferin-lusiferase is injected into the cuvette and the relative light units are read after some seconds. Standardization is made internally.

An improvement of the last mentioned method is the measuring of AEC (adenylate energy charge). It is determined by

$$
\mathrm{AEC}=\frac{\mathrm{ATP}+0.5 \mathrm{ADP}}{\mathrm{ATP}+\mathrm{ADP}+\mathrm{AMP}}
$$

We have made some attempts to determine the AEC according to the method described by BRoOKEs et al. (1983). Theoretically the AEC should well describe the activity of cells. If the AEC is high (0.7-1.0), the cells are metabolically active and if the AEC is low (under 0.4 ) the cells are metabolically passive.

A more usual method for determining the soil biomass is for example by chloroform fumigation (JenKINSON and Powlson, 1976). The microbial cells are killed by chloroform and the fumigated soil is inoculated with a very small amount of fresh soil. The cell 
matter of the chloroform-killed micro-organisms is now degraded by the micro-organisms of fresh soil to $\mathrm{CO}_{2}$. According to the literature, $40-50 \%$ of cell matter degrades during this test to $\mathrm{CO}_{2}$ (ANDERSON et al., 1981; Jenkinson and Powlson, 1976; 1980).

Determination of metabolic activity of microbial cells

$\mathrm{CO}_{2}$ production by soil micro-organisms measures the general activity of soil. This test can be carried out in the field or in the laboratory. In both cases, a known amount of $\mathrm{NaOH}$ is left for some hours to trap $\mathrm{CO}_{2}$ from a known surface area of soil or from a known weight unit. The remaining, unbound $\mathrm{NaOH}$ is titrated with $\mathrm{HCl}$. $\mathrm{CO}_{2}$ can be also measured gas-chromatographically with a thermal conductivity detector.

Carbon dioxide formation from different carbon-rich matter in soil can also be used as a measure of microbial activity. We have used such substrates as filter paper, straw or cellulose. We put the substrate into a polyester bag. The bag is buried in the ploughing layer for some months, usually for the whole growing season. After incubation, the weight losses are measured. Typically, the weight losses have been between 20 and $50 \%$ during one summer (Mettälä et al., 1982 and Silvo, 1983).

General soil metabolic activity can also be measured by enzyme assays. We have measured the dehydrogenase activities and nitrification potentials, which are more sensitive for pesticides than the measuring of the numbers of different microbial groups (Heinonen-TAnski et al., 1984).

Dehydrogenases are very common in many biochemical cycles. We use TTC, 2,3,5-triphenyltetrazolium chloride, as an electron acceptor. The incubation was $24 \mathrm{~h}$ at $26-$ $27^{\circ} \mathrm{C}$. Dehydrogenases transform triphenyltetrazolium chloride to TPF, triphenylformazan, which can be measured spectrophotometrically after the extraction. According to the literature, the red triphenylformazan is usually extracted by methanol, chloroform or carbon tetrachloride (THALMANN, 1968), but we have used ethanol successfully for this purpose. It is much safer for laboratory workers than any other solvent mentioned above and it is not so volatile as methanol or chloroform. Furthermore, the price of methanol is $170 \%$, carbon tetrachloride $280 \%$ and chloroform $400 \%$ of the price of ethanol (prices in Sept. 1984). According to our experience the extraction of TPF by ethanol is quantitative from sandy as well as from clay soils tested. Our standard curves are accurate, the parallel results are close to each others and the results from the blanks are low.

We have measured the nitrification potential by adding ammonium sulfate or water to air-dried soil. The nitrate concentration of soil has been measured at the beginning and at the end of 15 days' incubation. The nitrification potential has been counted by subtracting the original nitrate concentration from the nitrate concentration formed in the soil incubated with ammonium sulfate and also by subtracting the nitrate formed by mineralization in soil incubated with water. This method has been earlier used by MüLLER et al., (1981).

\section{Conclusion}

Some correlations between the results using different methods can be seen in Table 1 which originally has been published by Mettälä et al., (1982).

All the methods have their advantages and disadvantages. They measure different things. It would be useful to use different methods simultaneously in the same soil if we want to know the effects of rotation, irrigation, fertilization or pesticide treatment ect. on soil biological activity, because probably not all microbial activities are affected by a special treatment, but possible only some of them. 
Table 1. Correlation between microbiological tests (MettäLÃ et al. 1982).

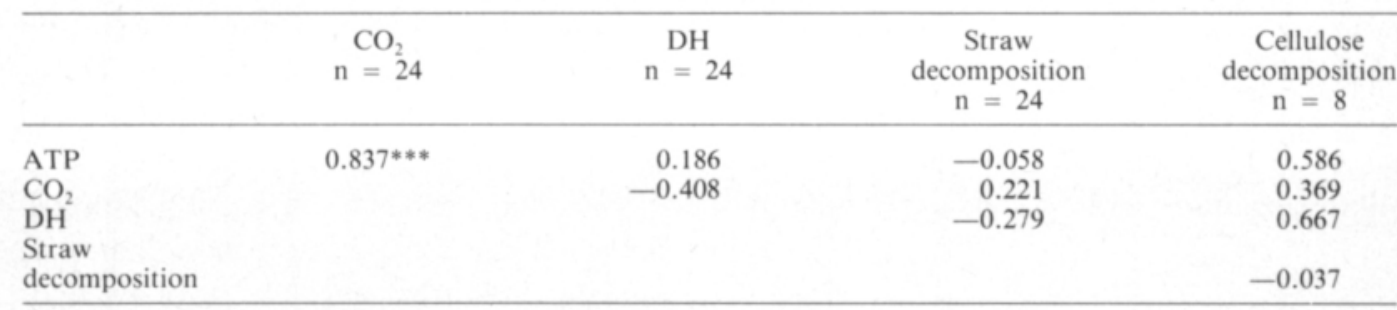

$\mathrm{DH}=$ dehydrogenase activity, ${ }^{* * *}=$ correlation significant at $\mathrm{p}=0.001$.

\section{Literature}

Anderson, J.P.E., Armstrong, R.A. \& Smith, S.N. 1981. Methods to evaluate pesticide damage to the biomass of the soil microflora. Soil Biol. Biochem. 13: 149-153.

ANON. 1979. Lumit application. Microbial biomass in soil. No 508. Lumac Systems AG.

Brookes, P.C., Tate, K.R. \& Jenkinson, D.S. 1983. The adenylate energy charge of the soil microbial biomass. Soil Biol. Biochem. 15: 9-16.

Fuhrman, J.A. \& Azam, F. 1982. Thymidine incorporation as a measure of heterotrophic bacterioplankton production in marine surface waters: evaluation and field results. Mar. Biol. 66: 109-120.

Heinonen-Tanski, H., Sil.vo, R. \& Kankila, J. 1984. The effect of a pesticide programme for sugar beet on soil microbial activity. Behaviour and side effects of pesticides in soil. Versailles, June 4-8, 1984. Ed. M. Hascoet. In press.

Jenkinson, D.S. \& Powison, D.S. 1976. The effects of biocidal treatments on metabolism in soil. 1. Fumigation with chloroform. Soil Biol. Biochem. 8: $167-177$.

Jenkinson, D.S. \& Powlson, D.S. 1980. Measurement of microbial biomass in intact soil cores and in sieved soil. Soil Biol. Biochem. 12: 579-581.

mettal ä, A., Koponen, M., Pirinen, H. \& Korkman, J.
1982. The effect of fertilization and crop rotation on soil chemical and biological properties in field trials on a clay soil in Southern Finland. J. Scient. Agric. Soc. Finl. 54: 331-344.

MeYer-ReIL, L.-A. 1978. Autoradiography and epifluorescence microscopy combined for the determination of number and spectrum of actively metabolizing bacteria in natural water. Appl. environm. Microbiol. 36: $506-512$.

Muller, M.M., Rosenberg, C., Siltanen, H. \& Wartio VAARA, T. 1981. Fate of glyphosate and its influence on nitrogen-cycling in two Finnish soils. Bull. environm. Contam. Toxicol. 27: 724-730.

RIEMANN, B. 1982. Personal communication.

Sııvo, R. 1983. Sokerijuurikkaan ja sipulin viljelyssả käytettyjen torjunta-aineiden vaikutus maan mikrobeihin. M Sc. thesis. Department of Microbiology, University of Helsinki.

TAYLOR, C.B. 1951. The nutritional requirements of the predominant bacterial flora of the soil. Proc. Soc. Appl. Microbiol. 14: 101-119.

Torsvik, V.L. \& Goksøyr, J. 1978. Determination of bacterial DNA in soil. Soil Biol. Biochem. 10: 7-12.

Ms received July 16, 1984 


\section{SELOSTUS}

\section{Maan mikrobiologisen aktiivisuuden ja} biomassan määrittäminen

Helvi Heinonen-Tanski, Aila Mettälä ja Riitta Silvo

Mikrobiologian laitos, Helsingin yliopisto, 00710 Helsinki 71

Perinteisesti maan mikrobiaktiivisuutta on tutkittu maaărittămăllă eri mikrobiryhmien pitoisuuksia viljelymenetelmin. Näissä määrityksissä on kuitenkin biologisista syistä johtuvia vaikeuksia.

Tăstă syystă nykyaaăn usein määritetãăn maan mikro- bien solumassan mảărä tai eri entsyymien aktiivisuuksia.

Tässä katsauksessa tarkastellaan eri menetelmien käyttömahdollisuuksia maamikrobiologiassa. 